\title{
Legitimasi Kedudukan Kepala Desa dalam Penyelesaian Sengketa Agraria
}

\section{Sri Anggraini Kusuma Dewi*}

Asia Institute of Technology $\mathcal{E}$ Business, Malang, Indonesia

\author{
Rezky Panji Perdana Martua Hasibuan \\ ADCO Law, Jakarta, Indonesia
}

\begin{abstract}
The agrarian disputes often occur in rural areas, considering that the majority of the livelihoods of rural communities are farmers. In this regard, rural communities also cannot be avoided from agrarian conflicts that occur between residents, including in terms of inheritance. This social legal research aims to analyze the factors causing the occurrence of agrarian conflicts in rural areas; and explain the role of the village head in dealing with disputes related to land. This empirical legal research uses a qualitative approach that is based on primary data and secondary data as obtained through a series of observations, interviews, and documentation. The results of the study indicate that rural communities tend to choose the head of village as the party that resolves agrarian disputes in rural areas. Therefore, the rural community perspective believes and considers the head of village to be able to provide a sense of community justice. The scheme used by the head of village is mediation or what is often called 'deliberation for consensus'.
\end{abstract}

KEYWORDS: Land, Customary Law, Head of Village, Amadanom, Malang

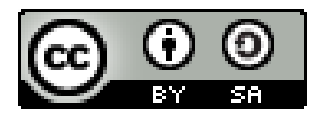

Copyright $(9) 2021$ by Author(s)

This work is licensed under a Creative Commons Attribution-ShareAlike 4.0 International License. All writings published in this journal are personal views of the authors and do not represent the views of this journal and the author's affiliated institutions.

HOW TO CITE:

Dewi, Sri Anggraini Kusuma \& Rezky Panji Perdana Martua Hasibuan, “Legitimasi Kedudukan Kepala Desa dalam Penyelesaian Sengketa Agraria" (2021) 1:2 Jurnal Kajian Pembaruan Hukum 309-340. DOI: <https://doi.org/10.19184/jkph.v1i2.24474>.

Submitted:30/05/2021 Reviewed: 06/06/2021 Revised: 18/06/2021 Accepted: 28/07/2021

* Corresponding authors' e-mail: kusumadewi2309@gmail.com 


\section{PENDAHULUAN}

Persoalan agraria di pedesaan berpotensi untuk menimbulkan gejolak sosial, seperti yang disampaikan oleh KPA yang mencatat total konflik agraria pedesaan tahun 2020 sejumlah 241 kasus. $^{1}$ Munculnya persoalan pertanahan pada Tahun 2020 telah menjadi bukti bahwa polemik agrarian telah menjadi isu yang fundamental. Tanah tidak hanya memiliki nilai ekonomis, namun juga dipandang sebagai sesuatu yang memiliki nilai historis dan religious yang kuat. Sehingga tidak jarang bahwa enigma pertanahan khususnya di pedesaan membawa stigma 'sampai mati pun tanah akan tetap dipertahankan'. ${ }^{2}$ Dengan demikian, diperlukan segala bentuk upaya yang mengikutsertakan seluruh elemen pemerintahan yang memahami karakter masyarakat terhadap pertanahan, termasuk kepala desa.

Penyelesaian sengketa agraria alternatif kepala desa perlu dikembangkan agar mendapat legitimasi dari masyarakat. Pada desa, tidak menutup kemungkinan orang perseorangan itu akan memiliki permasalahan sengketa tanah, baik itu tanah milik pribadi maupun tanah milik bersama. Kepala desa sangat penting peranannya untuk menyelesaikan permasalahan yang ditimbulkan oleh warganya sendiri sebelum menempuh jalur hukum di depan persidangan, oleh karena peranan kepala desa ini dipercaya dapat menyelesaikan masalah sengketa tanah ini dan para pihak yang berkaitan dengan cara damai. Hal ini terjadi karena di dalam perkumpulan hidup bersama, manusia yang merupakan makhluk

1 Catahu 2020 KPA Edisi I: Laporan Konflik Agraria di Masa Pandemi dan Krisis Ekonomi, by Sekretariat Nasional Konsorsium Pembaruan Agraria (KPA) (Jakarta, 2021) at 22.

2 Mirda Juniasri, Proses Permohonan Hak Atas Tanah Bekas Tanah Partikelir di Kelurahan Cipinang Kecamatan Pulo Gadung Jakarta Timur Universitas Diponegoro, 2004) [unpublished] at 35. 
sosial dan perlu adanya campur tangan orang lain dalam menyelesaikan masalah ini, seperti Kepala Desa. ${ }^{3}$

Pada kenyataan di lapangan, penyelesaian sengketa di pengadilan ternyata tidak mampu menarik minat masyarakat karena dianggap lebih rumit, biaya banyak, dan memakan waktu lama. ${ }^{4}$ Berdasarkan alasan tersebut, masyarakat lebih memilih penyelesaian sengketa melewati Kepala Desa dengan harapan bisa diselesaikan secara kekeluargaan. Kepala desa dalam suatu sistem kenegaraan Negara Republik Indonesia ini berperan penting dalam penyelesaian sengketa khususnya masalah tanah; 5 sebagaimana yang disesuaikan dengan adat daerah setempat agar tidak juga menghilangkan tradisi adat yang berlaku di desa itu dengan memberikan putusan yang seadil-adilnya. Seperti diketahui bahwa pemerintah telah mengundangkan Peraturan Pemerintah Nomor 11 Tahun 2019 tentang Desa agar memberikan keadilan terhadap masyarakat yang bersengketa, akan tetapi harus melihat sistem adat yang berlaku di desa tersebut.

Berdasarkan beberapa argumentasi di atas, terdapat tiga isu hukum yang akan dikaji dalam penelitian ini; yaitu: a) apa faktor penyebab masyarakat pedesaan menyelesaikan sengketa agraria kepada kepala desa?; b) bagaimana mekanisme penyelesaian sengketa harta waris berupa tanah oleh Kepala Desa?; c) bagaimana dampak positif dan negatif penyelesaian sengketa agraria lewat kepala desa.

3 Bagus Oktafian Abrianto, “Eksistensi Peraturan Desa Dalam Sistem Ketatanegaraan Dan Perundang-Undangan Di Indonesia" (2011) 26:3 Yuridika 219-246 at 219-221.

4 Faisal, "Mediasi Penal dalam Penyelesaian Sengketa di Luar Pengadilan" (2011) 6:1 Pranata Huk 81-90 at 88.

5 Samuel Dharma Putra Nainggolan, "Kedudukan Kepala Desa Sebagai Hakim Perdamaian" (2018) 3:1 Ubelac 54-67 at 58. 


\section{METODE}

Jenis penelitian yang digunakan adalah jenis penelitian hukum empiris. Penelitian hukum empiris ini menggunakan pendekatan kualitatif yang didasarkan atas hasil pengumpulan data. Hasil pengumpulan data serta pengumpulan informasi melalui studi kepustakaan untuk menjawab semua pernyataan dalam permasalahan yang akan diteliti dan kemudian dilakukan pengujian fakta yang terdapat pada masyarakat untuk mencari kebenaran dalam suatu proses penelitian. Penelitian hukum empiris ini bertitik tolak dari data primer sebagaimana diperoleh melalui serangkaian observasi, wawancara, dan dokumentasi.

\section{FAKTOR PENYEBAB TERJADINYA SENGKETA AGRARIA}

Proses penyelesaian konflik agraria seringkali melibatkan pihak yang banyak, baik negara ataupun institusi sosial seperti lembaga swadaya masyarakat (LSM). Upaya penyelesaian sengketa pertahanahan juga kerap kali menghadapi jalan buntu sehingga menjadi konflik yang berlarut-larut. ${ }^{6}$ Menurut Nurdin, ${ }^{7}$ munculnya problematikan pertanahan disebabkan karena adanya perbedaan/benturan nilai, perbedaan pemahaman terkait informasi, data atau gambaran obyektif kondisi pertanahan setempat (teknis), maupun perbedaan/benturan kepentingan ekonomi.

Pembahasan mengenai akar permasalahan pertanahan ini dibagi dalam dua kelompok; yaitu baik secara umum maupun secara

6 Utang Rosidin, "Partisipasi Masyarakat Desa Dalam Proses Pembentukan Peraturan Desa yang Aspiratif" (2019) 4:1 J Bina Mulia Huk 168-184 at 183.

7 Maharani Nurdin, “Akar Konflik Pertanahan di Indonesia" (2018) 3:2 J Huk Positum 126-141 at 127. 
khusus. Secara umum, berdasarkan pandangan Ningrum, ${ }^{8}$ pada hakikatnya sengketa tanah secara umum yang terjadi di Indonesia disebabkan oleh : (1) ketidaktertiban administrasi pertanahan masa lalu; (2) timbulnya ketimpangan struktur antara penguasaan dan kepemilikan tanah; (3) publikasi pendaftaran tanah yang bermasalah; (4) terjadinya peningkatan kebutuhan tanah, yang menyebabkan kenaikan harga tanah; (5) terdapat tumpang tindih terhadap peraturan perundang-undangan yang berlaku; (6) masih banyaknya terdapat tanah terlantar; (7) kurang cermatnya notaris dan pejabat akta tanah dalam menjalankan tugasnya; (8) belum terdapat persamaan persepsi atau interpretasi para penegak hukum khususnya hakim terhadap peraturan perundang-undangan; dan (9) para penegak hukum belum kurang berkomitmen untuk melaksanakan peraturan perundang-undangan secara konsekuen dan konsisten.

Terdapat dua faktor timbulnya sengketa bidang pertanahan, yakni faktor hukum dan faktor non hukum. ${ }^{9}$ Problematika kasus pertanahan diakibatkan karena belum terlaksananya kebijakan agraria secara utuh. ${ }^{10}$ UUPA merupakan induk dan dasar hukum yang mengatur mengenai bidang agraria. Namun, dalam berjalan waktu dibuatlah peraturan perundang-undangan yang berkaitan dengan sumber daya agraria tetapi tidak menempatkan UUPA

8 Herlina Ratna Sambawa Ningrum, “Analisis Hukum Sistem Penyelesaian Sengketa Atas Tanah Berbasis Keadilan” (2014) 1:2 J Pembaharuan Huk 219227 at 223.

9 Nurdin, supra note 8 at 129-130.

10 Budi Sastra Panjaitan, "Pengadilan Landreform Sebagai Wadah Penyelesaian Kasus Pertanahan" (2020) 4:1 Justitia J Huk 19-38, online: <http://journal.umsurabaya.ac.id/index.php/Justitia/article/view/3966> at 24. 
sebagai Undang-Undang induknya, bahkan justru menempatkan UUPA sejajar dengan Undang-undang Agraria. ${ }^{11}$

Selain itu, pengaturan pada bidang agraria masih belum mengacu pada nilai-nilan Pancasila dan Pasal 33 UUD 1945 tentang moral, keadilan, hak asasi, dan kesejahteraan. ${ }^{12}$ Jika dilihat dalam banyak kasus pertanahan, hak-hak rakyat pemilih tanah kerap kali dibiarkan. ${ }^{13}$ Di sisi lain, upaya hukum melalui melalui jalur litigasi terkadang tidak pernah menuntaskan persoalan. ${ }^{14}$ Selain itu juga, para pihak yang melakukan jalur hukum akibat tidak menerima tanahnya diokupasi pihak lain tidak pernah memperoleh kepastian hukum. Bahkan jika kita lihat dalam proses penyelesaian perkara melalui jalur litigasi, akan memakan tenaga, biaya yang tinggi, dan waktu yang lama, ${ }^{15}$ belum lagi bila terjebak dengan mafia peradilan, ${ }^{16}$ maka keadilan tidak pernah berpihak kepada yang benar. Hal ini tentunya telah melanggar prinsip peradilan kita yang sederhana, cepat dan berbiaya murah. Selain itu, pemerintah gagal menyelesaikan berbagai konflik pertanahan. ${ }^{17}$

11 Henry Sinaga, Disharmonisasi Undang-Undang Pokok Agraria dengan UndangUndang Sektoral Pengelolaan Sumber Daya Alam di Indonesia Universitas Sumatera Utara, 2017) at 138.

12 Nurdin, supra note 8 at 129.

13 D Anatami, "Tanggung Jawab Siapa, Bila Terjadi Sertifikat Ganda Atas Sebidang Tanah" (2017) 12:1 J Huk Samudra Keadilan 1-17, online: $<$ https://www.ejurnalunsam.id/index.php/jhsk/article/view/88> at 2-4.

14 Nurdin, supra note 8.

15 Syafrida, "Alternatif Penyelesaian Sengketa sebagai Solusi Mewujudkan Asas Pemeriksaan Perkara 'Sederhana, Waktu Singkat dan Biaya Murah'” (2020) 7:4 SALAM J Sos dan Budaya Syar-i 353-370 at 353.

16 Artidjo Alkostar, "Masalah Mafia Peradilan dan Penanggulangannya” (2002) 9:21 J Huk IUS QUIA IUSTUM 1-8 at 1-2.

17 Nurdin, supra note 8 at 132. 
Selain faktor hukum diatas, konflik pertanahan juga disebabkan oleh beberapa faktor non hukum, yang oleh Marsela ${ }^{18}$ perkara pertanahan tersebut secara garis besar dikelompokkan menjadi: ${ }^{19}$ Pertama, tumpang tindih penggunaan tanah. Sejalan dengan perkembangan zaman, pertumbuhan penduduk yang cepat mengakibatkan jumlah penduduk bertambah. ${ }^{20}$ Maraknya terjadi alih fungsi lahan, menuntut peran pemerintah daerah untuk tetap menjaga ketersediaan tanah. Tumpang tindih penggunaan tanah, terkait dengan kebijakan pemerintah dalam pemanfaatan tanah tidak sesuai dengan rencana tata ruang. Kedua, nilai ekonomi tanah tinggi. Kebijakan pemerintah orde baru memunculkan problematika hingga saat ini terkait sengketa penguasaan sumber daya pertanahan antara pemilik dengan pemilik modal yang difasilitasi oleh pemerintah. Sengketapun timbul bukan saja mengenai kepemimpinan tanah tetapi juga menyangkut penguasaan areal untuk perkebunan. ${ }^{21}$

Ketiga, kesadaran masyarakat meningkat. Pesatnya perkembangan globalisasi memberikan peningkatan dalam keilmuan dan teknologi yang berdampak terhadap peningkatan kesadaran masyarakat.22 Pola pikir masyarakat terhadap penguasaan tanah pun ikut berubah. Terkait dengan tanah sebagai aset pembangunan, maka muncul perubahan pola pikir masyarakat terhadap penguasaan tanah, yaitu tidak menempatkan tanah sebagai sumbar produksi akan tetapi

18 Marsella, "Perspektif Penanganan Sengketa Pertanahan Di Badan Pertanahan Nasional" (2015) 2:2 J Ilm Penegakan Huk 101-107 at 104.

19 Anatami, supra note 14 at 9-11.

20 Ibid.

${ }^{21}$ Fransiskus X Gian Tue Mali, “Negara vs Masyarakat: Konflik Tanah di Kabupaten Nagekeo, NTT” (2015) 11:2 J Kaji Polit Dan Masal Pembang 16571666 at 1658.

22 Ana Puji Astuti \& Anike NUrmalita Rps, “Teknologi Komunikasi Dan Perilaku Remaja" (2018) 3:1 J Anal Sosiol 91-111 at 91-93. 
menjadikan tanah sebagai sarana untuk investasi atau komoditas ekonomi.

Keempat, tanah tetap. Perkembangan jumlah penduduk membuat bertambahnya kasus sengketa tanah. ${ }^{23}$ Pertumbuhan penduduk yang sangat cepat baik melalui kelahiran maupun migrasi serta urbanisasi, sementara jumlah lahan yang tetap menjadikan tanah sebagai komoditas ekonomi yang nilainya sangat tinggi, sehingga setiap tanah dipertahankan mati-matian. Dan Kelima, kemiskinan. Kemiskinan merupakan masalah kompleks yang dipengaruhi oleh berbagai faktor yang saling berkaitan, antara lain tingkat pendapatan, kesehatan, pendidikan, akses terhadap barang dan jasa, lokasi, geografis, gender, dan kondisi lingkungan. Kemiskinan tidak lagi dipahami hanya sebatas ketidakmampuan ekonomi, tetapi juga kegagalan menemui atau sekelompok orang dalam menjalani kehidupan secara bermartabat. ${ }^{24}$

Jika dilihat secara khusus, kasus sengketa tanah muncul sebagai konflik sosial politik, seperti yang dinyatakan oleh Panjaitan ${ }^{25}$, di berbagai wilayah di Republik Indonesia dapat diidentifikasikan dalam beberapa katagori sebagai berikut: Pertama, masalah sengketa atas keputusan pengadilan oleh pihak yang bersengketa atas keputusan pengadilan.

a. Kasus penguasaan dan kepemilikan. Konflik pertanahan yang berkaitan dengan masalah penguasaan dan pemilikan tanah mencakup perbedaan persepsi, nilai atau pendapat, kepentingan

23 Layyin Mahfiana, "Sengketa Kepemilikan Hak Atas Tanah di Kabupaten Ponorogo" (2013) 7:1 Kodifikasia 83-102 at 83.

24 Zaili Rusli, Chalid Sahuri \& Dadang Mashur, "Penerapan Social Enterpreneurship dalam Memberdayakan Masyarakat Miskin Perkotaan" (2011) 2:2 J Kebijak Publik 70-83 at 70.

25 Panjaitan, supra note 11. 
mengenai status penguasaan di atas tanah tertentu yang tidak atau belum diletakkan hak (tanah Negara), ataupun yang telah diletakkan hak oleh pihak tertentu.

b. Kasus Penetapan dan Pendaftaran Tanah. Dalam hal ini, konflik disebabkan karena terjadinya perbedaan persepsi, nilai atau pendapat, kepentingan mengenai proses penetapan hak dan pendaftaran tanah yang merugikan pihak lain yang menimbulkan anggapan tidak sahnya penetapan perizinan di bidang pertanahan.

c. Kasus Batas Bidang Tanah. Konflik tersebut timbul berkaitan dengan letak, batas dan luas bidang tanah yang diakui satu pihak yang telah ditetapkan oleh Badan Pertanahan Nasional Republik Indonesia maupun yang masih dalam proses penetapan batas.

d. Kasus Ganti Rugi Eks Tanah Partikelir. Berkaitan dengan tanah partikelir, konflik lebih disebabkan oleh perbedaan persepsi, pendapat, kepentingan atau nilai mengenai keputusan tentang kesediaan pemerintah untuk memberikan ganti kerugian atas tanah partikelir yang dilikuidasi.

e. Kasus tanah Ulayat. Konflik berkaitan dengan tanah ulayat yaitu adanya perbedaan persepsi, nilai atau pendapat, kepentingan mengenai status ilyat dan masyarakat hukum adat di atas areal tertentu baik yang telah diterbitkan hak atas tanah maupun yang belum, akan tetapi dikuasai oleh pihak lain.

f. Kasus Tanah Landreform. Sengketa ini disebabkan karena adanya perbedaan pemahaman berkenaan dengan status penguasaan serta kepemilikan tanah, prosedur, penetapan biaya ganti rugi, penentuan pembagian tanah, dan subjek maupun objek dari suatu tanah.

g. Kasus Pengadaan Tanah. Sengketa ini seringkali timbul berkenaan dengan penetapan status hak tanah yang diperoleh dari adanya proses pengadaan tanah; yang meliputi proses ganti 
rugi, proses pengadaan maupun pelepasan tanah, dan lain sebagainya.

h. Kasus Pelaksanaan Putusan. Konflik ini berhubungan dengan pelaksanaan atas keputusan pengadilan. Lumrahnya, konflik ini terjadi diakibatkan adanya perbedaan pandangan atas penindaklanjutan hasil dari putusan pengadilan.

Meskipun demikian, berbagai mekanisme diatas seringkali di abaikan oleh para pihak. Hal tersebut dikarenakan masyarakat memiliki perspektif bahwa terdapat hal-hal administratif yang justru memberatkan masyarakat untuk mengadu kepada pihak yang berwenang. ${ }^{26}$ Oleh karena itu, acapkali pihak yang teralienasi atau dirugikan justru tidak menindaklanjuti permasalahan yang mereka hadapi. ${ }^{27}$ Hal tersebutlah yang menjadikan mediasi menjadi skema yang terbaik untuk membantu para pihak yang bersitegang menemukan suatu bentuk penyesuaian maupun kesepakatan. Pihak ketiga tersebut dapat ditentukan dari para pihak itu sendiri atau dipilih oleh pihak diluar para pihak. Sehingga, mediator merupakan seseorang yang dipilih oleh para pihak atau ditunjuk oleh seseorang yang memiliki kekuasaan. Padahal itu, kedua belah pihak yang bersengketa wajib menyetujui seluruh jasa yang dilakukan oleh mediator berorientasi untuk menyelesaikan masalah yang mereka hadapi. Pada fase pedesaan atau masyarakat kecil, lumrahnya tokohtokoh yang memiliki peran sebagai mediator juga berperan sebagai hakim maupun arbiter. Bagaimanapun, masyarakat pedesaan masih

26 Dimas Ramdhana Prasetya, "Analisis Pegelolaan Pengaduan Masyarakat dalam Rangka Pelayanan Publik ( Studi Pada Dinas Komunikasi dan Informatika Kota Malang )" (2013) 1:6 J Adm Publik 1151-1158, online: $<$ http://administrasipublik.studentjournal.ub.ac.id/index.php/jap/article/view /182> at 1152.

27 Dudi Badruzaman, "Perlindungan Hukum Tertanggung dalam Pembiayaan Klaim Asuransi Jiwa" (2019) 3:1 Amwaluna J Ekon dan Keuang Syariah 96114 at 97-98. 
menghormati adanya tetua desa sebagai tokoh yang yang dapat menindak lanjuti permasalahan yang ada, sehingga pandangan masyarakat terhadap seseorang yang dihormati dapat berdampak positif untuk memberikan suatu keputusan dan menegakkan keputusan itu secara substantif.

\section{FAKTOR PENYEBAB PENYELESAIAN SENGKETA AGRARIA MELALUI KEPALA DESA}

Persoalan dalam masyarakat yang menyangkut keperdataan diselesaikan lewat jalan adat, hukum yang tentu peran kepala desa disini yang paling besar sebagai mediatornya. Sehingga ketika ada persoalan maka diselesaikan dengan pertemuan antara pihak-pihak yang bersengketa dengan pihak pemerintahan desa setempat. Dalam kondisi seperti ini kepala desa selalu memosisikan diri sebagai orang yang paling dianggap tahu dengan mekanisme penyelesaiannya. Sebagian besar masyarakat di daerah pedesaan, memiliki pendidikan yang rendah sehingga mereka tidak mengerti dengan apa yang menjadi permasalahannya itu, yang penting bagi mereka adalah tentang pendapatan pembagian harta warisan tersebut ke tangan mereka dengan adil dan sesuai dengan kepuasan hati mereka. Kebanyakan dari mereka dalam pembagian harta waris sering kali tidak memakai mekanisme sesuai dengan undang-undang, namun mereka memakai kesepakatan bersama dari pihak-pihak yang mempunyai hak dari harta waris yang ditinggalkan oleh pewaris. Hal ini mengakibatkan ketika di kemudian hari ada pihak-pihak yang merasa dirugikan menimbulkan persengketaan. Dalam penyelesaian sengketa ini kebanyakan dari mereka tidak memakai mekanisme sesuai dengan undang-undang dikarenakan kurang pemahaman mereka sehingga mereka lebih memakai sistem non ligitasi melewati kepala desa sebagai mediatornya atau mediasinya. 
Secara praktik, menurut Rahayu ${ }^{28}$, terdapat beberapa faktor yang mengakibatkan dalam proses sengketa pembagian harta waris berupa tanah lebih efektif melalui kepala desa daripada ke jalur litigasi, antara lain tingkat pendidikan masyarakat yang rendah, mekanisme di pengadilan butuh waktu yang panjang, biaya yang cenderung mahal, dan paradigma masyarakat yang konvensional (tradisional). Selain tingkat pendidikan yang masih sangat kurang sering kali juga pola pikir mereka itu sulit untuk diarahkan dalam setiap sengketa untuk diselesaikan lewat jalur ligitasi karena kondisi pola pikir mereka lebih mengedepankan jalur non ligitasi yaitu lewat kepala suku atau kepala desa sebagai orang yang sangat dipercayai dan dianggap dapat memberikan rasa keadilan masyarakat.

\section{SKEMA PENYELESAIAN SENGKETA AGRARIA OLEH KEPALA DESA}

Penyelesaian perselisihan yang terjadi di Desa sebagaimana diakibatkan adanya konflik mengenai warisan agraria sejatinya mengacu pada ada ketentuan umum mengenai hukum waris yang berlaku di Indonesia. Sehingga, dasar penyelesaian tersebut tidak mengacu pada penyelesaian perselisihan secara perdata semata. Terhadap masalah waris, perlu dimengerti bahwa hukum waris memiliki berbagai ketentuan yang eksklusif dengan memberikan kategorisasi pada aspek hukum perdata, baik barat, Islam, maupun adat.

${ }^{28}$ Sri Lestari Rahayu, Mulyanto \& Anti Mayastuti, "Penguatan Fungsi Kepala Desa Sebagai Mediator Perselisihan Masyarakat Di Desa" (2016) 95:2 Yust J Huk 340-360 at 356. 
Penggunaan dasar hukum dalam penyelesaian perselisihan agraria sejatinya diberikan wewenang Nya kepada para pihak yang sedang berselisih. Pada aspek perselisihan sengketa Agraria yang berada di masyarakat, Strategi penyelesaian terbaik merupakan strategi khas Indonesia, yaitu melakukan musyawarah untuk mufakat dengan para ahli waris. Namun, bilamana musyawarah untuk mufakat tidak memberikan hasil yang diharapkan, maka para pihak yang berhubungan dengan para ahli waris dapat mengajukan suatu bentuk gugatan ke pengadilan. Berangkat dari berbagai macam persoalan khususnya permasalahan tanah yang terjadi di daerah pedesaan, lahirlah sebuah pemikiran untuk menggagas kembali sebuah model mekanisme penyelesaian sengketa tanah alternatif melalui kepala desa. Model penyelesaian ini umum diidentifikasikan sebagai penyelesaian sengketa jalur non ligitasi atau luar pengadilan.

Berdasarkan dari permasalahan yang timbul, adanya sedikit pengantar atau gambaran mekanisme pengajuan sengketa oleh masyarakat kepada kepala desa, yang tentunya bertujuan untuk mencari keadilan terhadap obyek yang disengketakan hingga menemukan titik temu atau keputusan berdasarkan kesepakatan bersama. Dalam hal ini, kepala desa memberikan statement berkaitan tentang dampak yang nantinya ditimbulkan oleh masyarakat penyelesaian sengketa tanah melalui mekanisme kepala desa, berikut adalah contoh proses pengajuan penyelesaian sengketa tanah mulai dari adanya permasalahan sampai ke kepala desa adalah sebagai berikut: 


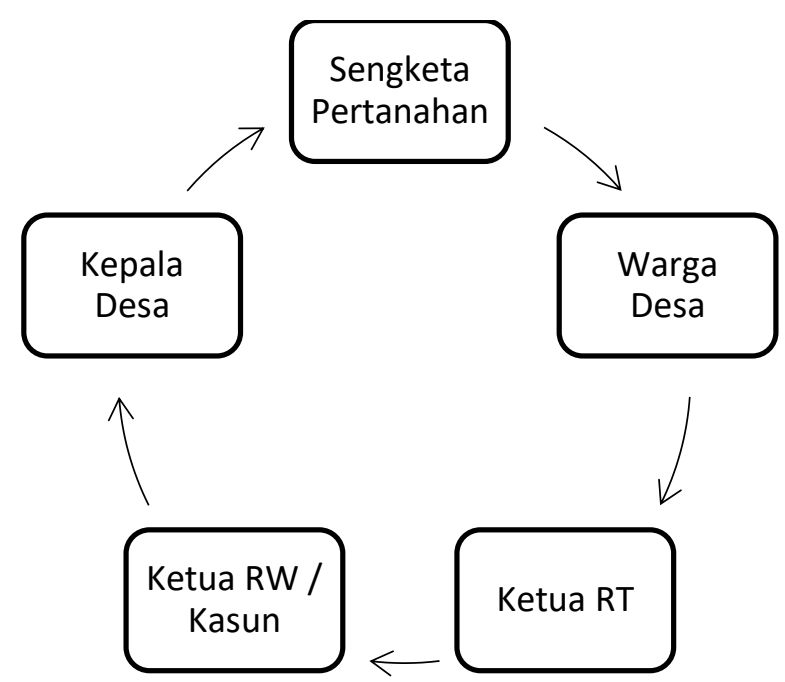

Gambar 1. Mekanisme

\section{Sumber : Hasil Penelitian Lapangan Desa Amadanom Kecamatan Dampit Kabupaten Malang}

Dari skema atau bagan yang ada di atas memberikan sedikit gambaran terkait tentang pengajuan penyelesaian sengketa tanah mulai dari masyarakat hingga sampai pada kepala desa, tidak semata-mata ketika menghadapi suatu permasalahan pengajuannya langsung ke kepala desa ada tahapan-tahapan tertentu seperti yang digambarkan di atas.

Adapun sedikit deskripsi dari pada skema yang ada di atas yaitu, setelah ketua RT (Rukun Tetangga) mendapat laporan (mengetahui adanya indikasi sengketa), maka ketua RT sebagai pihak pertama dalam tahapan di atas maka akan mendatangi kedua belah pihak secara personal sebagai tindakan pencegahan untuk memberikan pengertian kepada kedua belah pihak, hal ini dilakukan dengan tujuan untuk meredam sengketa yang larut-larut, selanjutnya apabila tindakan preventif itu masih saja belum berhasil, maka ketua RT akan mendatangkan kedua belah pihak untuk di pertemukan di kantor RT dalam upaya mediasi. Apabila sengketa tersebut belum dapat terselesaikan oleh ketua RT, maka akan dilaporkan kepada 
ketua RW (Rukun Warga). Pada tahapan ini, ketua RW melaksanakan upaya mediasi yang serupa, apabila tindakan ketua RW tidak mampu lagi untuk menyelesaikan perkara tersebut akan direkomendasikan kepada kepala desa.

Oleh kepala desa kedua belah pihak akan dipertemukan, dan kepala desa akan meminta keterangan dari kedua belah pihak atas permasalahan yang disengketakan, sekaligus kepala desa akan memanggil ketua RT dan ketua RW selaku yang berwenang dan juga sebagai saksi untuk dimintai keterangan terkait tentang latar belakang persengketaan. Berkumpulnya para pihak akan dilanjutkan dengan mediasi dalam rangka penyelesaian. Penyelesaian sengketa yang dipilih cenderung bersifat non ligitasi atau di luar pengadilan yang dianggap lebih praktis dan sederhana, meskipun hanya melibatkan peranan kepala desa setempat. Model penyelesaian yang demikian diklasifikasikan di Indonesia sebagai empat (4) jenis yaitu: ${ }^{29}$ (a) Negosiasi dimaknai sebagai komunikasi dua arah, ketika masing-masing pihak saling mengemukakan keinginannya. Negosiasi ini adalah proses untuk mencapai kesepakatan dengan pihak lain, suatu proses komunikasi yang dinamis dan beraneka ragam, atau bisa dikatakan, negosiasi ini merupakan proses tawarmenawar dari masing-masing pihak demi mencapai kesepakatan; (b) Mediasi adalah proses penyelesaian sengketa dengan perantara pihak ketiga (mediator), yaitu pihak yang memberikan timbal balik kepada para pihak untuk menyelesaikan sengketa. Namun, pada masing-masing pihak tidak terdapat kewajiban untuk menaati apa yang disarankan mediator. Pilihan penyelesaian sengketa melalui

29 Ros Angesti Anas Kapindha, Salvatia Dwi M \& Winda Rizky Febrina, "Efektivitas dan Efisiensi Alternatif Dispute Resolution (AD) Sebagai Salah Satu Penyelesaian Sengketa Bisnis di Indonesia" (2014) 4 Priv Law 1-14, online: <https://www.neliti.com/publications/26551/efektivitas-dan-efisiensialternative-dispute-resolution-adr-sebagai-salah-satu $>$ at 7-10. 
mediasi mempunyai kelebihan dari segi biaya, waktu dan pikiran bila dibandingkan dengan berperkara di pengadilan yang melatar belakangi kurangnya kepercayaan atas kemandirian lembaga peradilan dan kendala administrasi yang melingkupinya membuat lembaga pengadilan merupakan alternatif terakhir untuk menyelesaikan masalah sengketa pertanahan dan terkadang mereka enggan untuk memilih penyelesaian sengketa di pengadilan. Adapun prosedur yang harus ditempuh dalam mediasi, secara garis besar melalui empat tahap yaitu: (A) pengantar yang berisi penjelasan mediator tentang cara yang harus diikuti dan peranan komunikasi yang terbuka dan tidak melakukan intervensi; (B) memahami isu dalam sengketa dengan cara memberikan kesempatan kepada masing-masing pihak untuk mengemukakan pendapatnya mengenai hal-hal yang disengketakan, menjajaki alternatif untuk mencari kesepakatan; (C) Konsiliasi prosesnya hampir sama dengan mediasi, tetapi biasanya oleh undang-undang. Ketika suatu pihak diwajibkan hadir, konsiliator cenderung menekan dan bertanggung jawab atas norma sesuai undang-undang atau badan hukum terkait, dan langkah hukum yang akan diambil bila kesepakatan tidak tercapai; (D) Arbitrase adalah penyelesaian atau sengketa oleh seorang hakim atau para hakim berdasarkan persetujuan bahwa para pihak akan tunduk pada keputusan yang diberikan oleh hakim atau para hakim.

Dari proses yang sudah dipaparkan diatas kebiasaan dari masyarakat desa memilih jalur yang mungkin bagi mereka dapat memberikan rasa keadilan yaitu dengan jalur non ligitasi. Tindakan penyelesaian melalui mediasi yang dilakukan oleh kepala desa selaku penyelenggara pemerintahan desa, membebankan penyelesaian kepada pejabat pemerintahan desa. Kepala desa dalam permasalahan sengketa tanah yang sedang terjadi ini berlaku sebagai 
mediator dan saksi antara kedua belah pihak yang berperkara, dan dianggap bahwa penyelesaian sengketa melalui kepala desa ini merupakan media terpercaya serta media penyelesai yang bijak.

Melihat potensi terjadinya sengketa tersebut, secara prosedural masyarakat dalam menyelesaikan masalah dilakukan secara berjenjang dari tingkat paling rendah. Dalam lingkup desa, penyelesaian diajukan pertama kepada ketua RT, apabila pada tahap tersebut masih belum dapat terselesaikan akan dilimpahkan pada tingkat ketua RW bila di daerah perkotaan, akan tetapi di daerah pedesaan mereka sering menyebutnya kasun (kepala dusun) sebelum di bawahnya ke desa yang dikepalai oleh seorang kepala desa yang apabila belum ditemukan titik tentang atau titik temunya antara kedua belah pihak yang bersengketa, dan seluruhnya dalam hal ini para pemimpin-pemimpin desa mereka berperan sebagai seorang mediator dalam permasalahan yang dihadapi oleh warga desa Amadanom.

Peranan dari kepala desa esensial dalam penyelesaian permasalahan yang ada di desa, baik itu permasalahan internal maupun permasalahan eksternal. Pada hakikatnya kepala desa adalah orang dengan kuasa tertinggi dibandingkan dengan masyarakat pada umumnya, dengan kedudukannya itulah peranan kepala desa sangat diperlukan oleh masyarakat desa Amadanom.

Permasalahan sengketa tanah yang paling mendasar yakni terjadinya konflik antar keluarga yang memperebutkan harta kekayaan yang akan di berikan kepada ahli waris yang berhak. Permasalahan ini bermula ketika pewaris tidak mempunyai seorang anak kandung dan dia mengambil atau mengasuh anak dari hasil adopsi anak orang lain. Secara tidak langsung, harta peninggalan pewaris akan jatuh ke tangan anak tersebut, akan tetapi keluarga kandung dari si pewaris 
ini tidak menerima keputusan tersebut. Dalam permasalaha ini anak tersebut bukanlah anak kandung dari si pewaris, sehingga sepatutnya tidak berhak untuk menerima warisan yang ditinggalkan oleh pewaris.

Salah satu contoh permasalahan di desa Amadanom Kecamatan Dampit Kabupaten Malang yakni berkaitan dengan perebutan warisan yang diberikan oleh pewaris. Para ahli waris inilah yang mengalami perselisihan yang dipicu oleh adanya pihak ketiga yang ikut campur dalam proses pembagian harta waris. Tidak hanya itu, pembagian warisan yang tidak merata antara ahli waris menjadi sumber sengketa tanah ini. Permasalahan ini pernah terjadi pada masa jabatan kepala desa periode 2011-2016 yang dipimpin oleh B. Setyo Budi Handoko, kasus ini merupakan kasus warisan dari kepala desa sebelumnya yaitu Bapak Sarimin yang hingga saat ini belum terselesaikan dan masih dalam proses pengadilan, berikut beberapa contoh kasus yang terselesaikan dan belum terselesaikan:

Tabel 1

Penyelesaian Kasus Sengketa Tanah

Di Desa Amadanom Kecamatan Dampit Kabupaten Malang

\begin{tabular}{|c|c|c|l|c|}
\hline \multirow{2}{*}{ No } & \multirow{2}{*}{ Tahun / Periode } & \multirow{2}{*}{ Jmlh } & \multicolumn{2}{|c|}{ Penyelesaian } \\
\cline { 4 - 5 } & & & Kepala Desa & Pengadilan \\
\hline 1 & $2002-2007$ & 2 & Terselesaikan & - \\
\hline 2 & $2007-2011$ & 2 & Terselesaikan & - \\
\hline 3 & $\begin{array}{c}2011-\text { hingga } \\
\text { sekarang }\end{array}$ & 1 & Terselesaikan & - \\
\hline
\end{tabular}




\begin{tabular}{|c|c|c|c|c|}
\hline 4 & & & Dalam proses \\
pendaftaran \\
sekarang & 1 & - & di \\
& & & & pengadilan \\
\hline
\end{tabular}

Sumber : Hasil Penelitian Lapangan Desa Amadanom Kecamatan

Dampit Kabupaten Malang

Berdasarkan tabel di atas dapat dipahami bahwa permasalahan sengketa tanah mulai dari tahun ke tahun mayoritas dapat terselesaikan dengan baik, ini disebabkan oleh peranan dari kepala desa yang krusial dalam penyelesaiannya. Sehingga dapat dipahami bahwa peranan kepala desa ini masih berpengaruh besar bagi warganya, akan tetapi dari permasalahan tersebut ada salah satu permasalahan yang masih dalam proses di pengadilan, karena ketidakpuasan dari para pihak untuk menyelesaikan permasalahan di depan kepala desa, maka dengan itu para pihak bersepakat untuk menyelesaikan permasalahan ke jalur pengadilan. Dari permasalahan di desa Amadanom itu mayoritas mampu diselesaikan oleh kepala desa, namun ada juga yang penyelesaian sengketa tanah tersebut menempuh jalur hukum pada umumnya.

Permasalahan sengketa tanah yang ada itu paling banyak tanah yang menjadi obyek persengketaan biasanya $\pm 2000-5000 \mathrm{~m}^{2}$, dan biasanya para pemimpin desa sebagai mediasinya memakai sistem kekeluargaan yang tepatnya adalah memakai sistem adat desa tersebut. Dan biasanya ketika kepala desa Amadanom tersebut memakai sistem kekeluargaan masyarakat desa tersebut yang bersengketa mereka mau dan mengikuti mekanisme yang dibuat oleh kepala desa yang selaku orang tertinggi di desa tersebut. Di dalam permasalahan itu ketua RW juga sebagai mediator dari penyelesaian sengketa itu, dan pernah juga mengalami 
permasalahan yang sama yaitu kasus sengketa tanah, beliau melakukan upaya dengan cara mempertemukan kedua belah pihak yang bersengketa dan dengan diberikan masukan-masukan terhadap pihak yang bersengketa tersebut dan bersama-sama untuk mencari jalan tengahnya atau jalan keluarnya, yang menurut beliau dari pada diselesaikan di pengadilan yang salah satu kendalanya memakan biaya yang cukup mahal, proses penyelesaiannya yang berbelit-belit, dan lain sebagainya beliau menyarankan agar di selesaikan dengan cara kekeluargaan yang masing-masing menerima apa yang menjadi kesepakatan bersama.

\section{PERAN KEPALA DESA SEBAGAI MEDIATOR TERHADAP SENGKETA DI DESA}

Adanya konflik yang memiliki keterkaitan dari dinamika interaksi sosial dan budaya di desa tentu menjadi di pekerjaan bersama agar dapat terkelola dengan baik. Hal ini wajib dilakukan agar seluruh lapisan masyarakat terhindar dari konflik horizontal maupun vertikal yang dapat menyebabkan adanya disintegrasi. Dengan demikian, diperlukan skema untuk mengantisipasi sekaligus saluran Penyelesaian sengketa antar warga di desa. Penyelesaian ini dilakukan dengan dasar musyawarah untuk mufakat, sehingga solusi terbaik dan memberikan rasa kemenangan bagi seluruh pihak adalah melalui skema mediasi. Pada lingkup desa, pihak yang berpotensi dan memiliki untuk menjadi mediator merupakan kepala desa sebagai pemimpin wilayah yang memahami kondisi secara riil mengenai hubungan warga masyarakat.

Perlu dimengerti, Undang-Undang Nomor 6 Tahun 2014 tentang Desa (UU Desa) memerlukan terminologi 'perselisihan' guna memberikan gambaran atas adanya konfrontasi atau inkompabilitas 
yang timbul di lingkungan pedesaan. Lebih dalam meninjau istilah tersebut, 'konflik' memiliki makna dalam bahasa Latin sebagai 'con' yang memiliki arti 'beriringan' dan 'fligere' yang bermakna 'tabrakan atau tumbukan'.30 Pada perspektif sosial, perselisihan dimaknai sebagai suatu aktivitas sosial yang dilakukan oleh dua pihak atau lebih -bahkan bisa berkelompok pula- yang mana salah satu diantara mereka berupaya untuk menyingkirkan satu sama lain secara destruktif. ${ }^{31}$ Oleh karena itu, konflik diartikan sebagai suatu proses di dalam kehidupan sosial yang berkaitan dengan adanya benturan kepentingan dan setiap subjek hukum yang melibatkan berbagai pihak lain sebagai salah satu bentuk konsekuensi adanya interaksi sosial yang disharmoni.

Oleh karena itu, di dalam suatu sistem interaksional yang memiliki solidaritas kuat sebagaimana berada dalam pedesaan, maka skema yang diambil untuk menyelesaikan suatu sengketa adalah alternative dispute resolution. Dengan demikian, kepala desa wajib memahami pengetahuan mengenai hal tersebut, sehingga, apabila kepala desa tidak memahami perihal mediasi; maka, hal tersebut akan mengakibatkan tidak berhasilnya proses mediasi dan tidak menghasilkan solusi yang terbaik bagi masyarakat di desa. ${ }^{32}$

Fungsi Kepala Desa dalam melaksanakan kewajiban menyelesaikan perselisihan masyarakat di desa sebagaimana yang dimaksud Pasal 26 (4) huruf k. Undang-Undang Nomor 6 Tahun 2014 tentang Desa yang menyatakan: Dalam melaksanakan tugas sebagaimana termuat

30 Mulyadi, “Konflik Sosial Ditinjau Dari Segi Struktur dan Fungsi” (2002) 14:3 Humaniora $1-18$ at 1.

31 Anam Miftakhul Huda \& Vembita Sapna Key, "Model Guyup Rembug Dalam Penyelesaian Konflik : Pada Konflik Antara Forpak Dengan Karang Taruna Di Desa Sidodadi" (2018) 4:2 Translitera J Kaji Komun dan Stud Media 1-16 at 4.

32 Rahayu, Mulyanto \& Mayastuti, supra note 31. 
pada ayat (1), Kepala Desa berkewajiban menyelesaikan perselisihan masyarakat di Desa menurut hemat peneliti tidak lain adalah fungsi kepala desa untuk berperan sebagai mediator. Secara etimologi, istilah mediasi berasal dari bahasa Latin, "mediare" yang berarti berada di tengah. ${ }^{33}$ Makna ini menunjuk pada peran yang ditampilkan pihak ketiga sebagai mediator dalam menjalankan tugasnya menengahi dan menyelesaikan sengketa antara para pihak. "Berada di tengah" juga bermakna mediator harus berada pada posisi netral dan tidak memihak dalam menyelesaikan sengketa. Ia harus mampu menjaga kepentingan para pihak yang bersengketa secara adil dan sama, sehingga menumbuhkan kepercayaan (trust) dari para pihak yang bersengketa.

Mediasi sebagai salah satu alternatif penyelesaian sengketa juga telah dikenal luas dan banyak digunakan berbagai pihak dalam menyelesaikan sengketa di luar pengadilan. Mediasi adalah intervensi terhadap suatu sengketa atau negosiasi oleh pihak ketiga yang dapat diterima, tidak berpihak dan netral yang tidak mempunyai kewenangan untuk mengambil keputusan dalam membantu para pihak yang berselisih dalam upaya mencapai kesepakatan. secara sukarela dalam penyelesaian permasalahan yang disengketakan. ${ }^{34}$ Sebagaimana Stephen Goldberg terkait mediasi bahwa mediasi didalam negosiasi memerlukan andil faksi ketiga. ${ }^{35}$ Secara ekstensif dalam Black Dictionary dijelaskan bahwa mediasi adalah "Mediation is private, informal dispute resolution process in which a neutral third person, the mediator, helps, disputing parties to

33 Syahrizal Abbas, Mediasi Dalam Hukum Syariah, Adat, dan Hukum Nasional (Jakarta: Kencana Prenada Media, 2009).

34 Christopher W Moore, The Mediation Process: Practical Strategies for Resolving Conflict (San Fransisco: Jossey-Bass Publisher, 2003).

35 Stephen Goldberg, Dispute Resolution Negotiation, Mediation and Other Processes (New York: Little Brown and Company, 1992). 
reach an agreement". "The Mediator has no power to impose a decision on the parties." 36

Kepala desa adalah tokoh yang dapat memainkan peran penting sebagai mediator dalam penyelesaian perselisihan dalam masyarakatnya. Hal ini tidak lepas dari posisi kepala desa yang pada umumnya merupakan tokoh yang disegani oleh lingkungan masyarakatnya, di samping menurut Undang-Undang Nomor 6 Tahun 2014 tentang Desa menyatakan bahwa kepala desa adalah pemimpin pemerintahan yang memiliki posisi yang kuat (berwibawa) sehingga diharapkan akan efektif dalam menjalankan peran sebagai seorang mediator atau penyelesai perselisihan. Pada umumnya dikenal tiga tipe mediator sebagaimana dikemukakan oleh Joseph Spence bahwa terdapat tiga tipe mediator yakni dapat diklasifikasikan sebagai social network type, authoritative type, dan independent type ${ }^{37}$ Pertama, social network mediators, yaitu mediator yang berperan dalam suatu penyelesaian sengketa atas dasar adanya hubungan sosial dengan para pihak yang bersengketa; Kedua, authoritative mediators, yaitu mediator yang berusaha membantu pihak-pihak yang bersengketa untuk menyelesaikan konflik dan memiliki posisi yang kuat (berwibawa), sehingga memiliki kapasitas untuk mempengaruhi hasil akhir proses mediasi. Ketiga, independent mediators, yaitu mediator yang menjaga jarak antar-pribadi maupun dengan persoalan yang tengah dihadapi. ${ }^{38}$ Fungsi kepala desa sebagai penyelesai perselisihan pada dasarnya merupakan mediasi yang memiliki bentuk antara social network mediators dan authoritative

36 Henry Black Campbell, Black's Law Dictionary (USA: Min West Publishing Co, 1990).

37 Joseph Spence, "Types of Mediators to Select From", (2010), online: Ezne Artic $<$ https://ezinearticles.com/?Types-of-Mediators-to-Select-From\&id=5133589>.

38 Ibid. 
mediators. Secara historis fungsi tersebut sejak dahulu dikenal sebagai hakim peradilan desa atau "dorpjustitie". ${ }^{39}$

Fungsi kepala desa sebagai penyelesai perselisihan sebagaimana diatur dalam Pasal 26 (4) huruf k Undang-Undang Nomor 6 Tahun 2014 tentang Desa tidak terlepas dari kenyataan historis bahwa di masa lalu di tingkat desa dan masyarakat hukum adat dikenal adanya peradilan desa dan atau peradilan adat. Sekalipun Pasal 6 ayat (1) PERMA Nomor 01 Tahun 2008 menyatakan Hakim Pengadilan Negeri yang dapat menjadi seorang mediator sedangkan pihak lain, yakni orang yang ditentukan sendiri oleh para pihak untuk bertindak sebagai mediator tapi harus terlebih dahulu memiliki sertifikat sebagai mediator, hal tersebut tidak berlaku jika proses mediasi terjadi di luar pengadilan sebagaimana yang dilakukan oleh kepala desa.

Kepala desa melaksanakan tugas sebagai penyelesaian perselisihan merupakan kewenangan yang bersumber dari atribusi berdasarkan Undang-Undang Nomor 6 Tahun 2014 tentang Desa. Konsekuensinya adalah seorang kepala desa tidak harus memiliki sertifikasi mediator untuk dapat melaksanakan tugas sebagai penyelesai perselisihan. Secara empiris di banyak masyarakat hukum adat lainnya keberadaan peradilan adat masih sangat berperan besar sebagai self regulating mechanism atau sering disebut sebagai community justice system yang bekerja secara informal namun otonom. ${ }^{40}$ Lembaga ini melalui mekanisme-mekanisme yang dimiliki berfungsi sebagai penyelesai, dan/atau sebagai pemulih situasi tertib

39 Nader \& Todd, supra note 30.

40 Kurnia Warman \& Syofiarti, "Pola Penyelesaian Sengketa Tanah Ulayat di Sumatera Barat (Sengketa antara Masyarakat vs Pemerintah)" (2012) 41:3 Masal Huk 407-415 at 408-410. 
pada umumnya. ${ }^{41}$ Sementara itu di luar peradilan adat yang dikenal dalam kesatuan masyarakat hukum adat (terutama yang terdapat pada desa-desa di Jawa) dikenal adanya peradilan desa yang dijalankan hakim perdamaian desa untuk menyelesaikan perkaraperkara tertentu. Perkara yang dapat ditangani oleh hakim perdamaian desa pada umumnya adalah perkara perdata, pidana ringan serta pelanggaran-pelanggaran tatanan/norma-norma hukum adat dimana kepala desa mendamaikan dan menyelesaikan perkara menurut asas-asas dan sistem adat/hukum adat serta kesadaran hukum masyarakat. Dalam konteks Indonesia peradilan desa dan atau peradilan adat merupakan "peradilan non-negara" atau "peradilan informal" yang hakikatnya adalah "penyelesaian sengketa ditingkat lokal" yang dilakukan oleh kepala desa, para pemuka adat, tokoh masyarakat, dan tokoh agama - kadang-kadang didasarkan pada tradisi, namun sering pula hanya berdasarkan pertimbangan subyektif para pemimpin warga tanpa dasar yang jelas atau mengacu kepada hukum negara maupun hukum adat. Menurut tinjauan Bank Dunia, fungsi kepala desa sebagai penuntasan setidaknya memiliki beberapa keunggulan. ${ }^{42}$ Pertama, untuk sebagian besar kasus kecil dan ringan, peradilan informal merupakan proses yang tepat dan efektif. Kedua, hakim perdamaian desa memiliki legitimasi dan otoritas lokal, yang tidak selalu dimiliki peradilan negara. Ketiga, prosedur dan substansinya sesuai dengan pendapat umum yang mengutamakan kerukunan. Keempat, tujuannya bersifat menghindari konflik dan bersifat restoratif; dan prosesnya bersifat cepat dan sangat murah. Kelima, efektif dan efisien bagi masyarakat pedesaan yang saling bergantung satu sama

41 Soetandyo Wignjosoebroto, Dari Hukum Kolonial Ke Hukum Nasional: suatu kajian tentang dinamika sosial-politik dalam perkembangan hukum (Yogyakarta: PT Raja Grafindo Persada, 1994).

42 Rahayu, Mulyanto \& Mayastuti, supra note 13 at 350. 
lain secara ekonomi dan sosial. Keenam, 60\% (enam puluh) persen responden menyatakan kepuasannya pada hakim perdamaian desa dibandingkan dengan 58 (lima puluh delapan) persen responden puas dengan pelaku peradilan formal.

Kelebihan yang dimiliki fungsi kepala desa sebagai penyelesai perselisihan yang demikian itu akan sangat signifikan dalam mengurangi arus masuknya perkara ke peradilan negara yang sekarang sudah kelebihan daya tampung. Banyak sengketa perdata dan perkara pidana adat, kasus "sandal jepit", atau delik aduan akan lebih efektif dan efisien diselesaikan oleh peradilan informal (peradilan adat) yang diharapkan dapat memberikan keadilan restoratif. 43

\section{DAMPAK PENYELESAIAN SENGKETA MELALUI KEPALA DESA}

Persoalan atau persengketaan khususnya persengketaan yang bersangkutan ihwal tanah, menjurus pada persengketaan tanah warisan yang menjadi akar masalah itu timbul akibat dari faktor internal keluarga yang merasa dirinya kurang puas dengan sebagaimana segala sesuatu yang telah diterima ahli waris yang berhak untuk menerima harta warisan tersebut. Persengketaan atau konflik pertanahan tentu berhubungan dengan banyak pihak. Hal tersebut disebabkan manakala terdapat masyarakat, maka akan timbul potensi konflik horizontal maupun vertikal. Padahal,

43 Budiyanto Budiyanto, "Penerapan Keadilan Restoratif (Restorative Justice) Dalam Penyelesaian Delik Adat" (2018) 1:1 Papua Law J 81-100 at 82; Teguh Hariyono, "Mediasi Penal sebagai Alternatif Upaya Penyelesaian Perkara Pidana di Luar Pengadilan" (2021) 2:1 J Penegakan Huk dan Keadilan 1-18 at $2-4$. 
sejatinya subjek hukum hanya akan mencegah adanya konflik tanpa menimbulkan aksi-aksi destruktif dan manusia hanya bisa meredam agar kekerasan tersebut tidak semakin besar. Hal ini terjadi dikarenakan penyelesaian konflik khususnya penyelesaian masalah persengketaan tanah hanyalah menggunakan pendekatan paradigma hukum.

Pada konteks penelitian ini, penanganan konflik persengketaan tanah yang dilakukan oleh kepala desa Amadanom Kecamatan Dampit Kabupaten Malang terhadap masyarakatnya yang notabene sering terjadi sengketa tanah itu bertujuan untuk memberikan kepastian hukum atau memberikan sedikit masukan terhadap pihakpihak yang bersengketa atas pemanfaatan, penggunaan, pemilikan, dan penguasaan tanah. Proses tersebut bertujuan agar tidak terjadi tumpang tindih penguasaan; tumpang tindih pemilikan tanah yang sepihak yang memicu terjadi konflik. Agar tidak terjadi konflik yang berkepanjangan, langkah-langkah yang harus di tempuh oleh kepala desa selaku pimpinan penyelenggara Negara di tingkat desa adalah memberikan pemahaman terhadap warganya akan masalah pertanahan. Dari berbagai pertanyaan yang ada khususnya soal sengketa tanah, ada beberapa hasil yang ditimbulkan masyarakat desa setempat melakukan proses penyelesaian sengketa melewati kepala desa, beberapa dampak tersebut dapat dibagi menjadi dua bagian; sejalan dengan penelitian yang dilakukan oleh Kamaludin $\mathrm{H}$. Ahmad dan Ongki. ${ }^{44}$

44 Kamaluddin Ahmad \& Ongki, "Peran Kepala Desa Dalam Menyelesaikan Konflik Antar Masyarakat Berdasarkan Peraturan Pemerintah Nomor 2 Tahun 2015 (Studi Kasus Di Desa Renda Kecamatan Belo Kabupaten Bima)" (2019) 7:1 Civ Pendidikan-Penelitian-Pengabdian Pendidik Pancasila dan Kewarganegaraan 58-69 at 59. 
Dampak Positif dari penyelesaian sengketa lewat kepala desa, terdiri dari beberapa bagian, yaitu: (1) Tidak mengeluarkan banyak biaya, dibandingkan penyelesaian lewat pengadilan; (2) Dapat disesuaikan dengan kelonggaran waktu para pihak untuk menyelesaikan persengketaan; (3) Dapat mempermudah analisis pokok-pokok latar belakang terjadinya sengketa. Dampak Negatif penyelesaian sengketa lewat kepala desa ini juga terbagi menjadi beberapa bagian, yaitu: (1) Kompetensi kepala desa yang sangat minim; (2) Hasil keputusan kepala desa yang tidak memberikan kepastian hukum; (3) Dimungkinkan kepala desa tidak bersikap netral. Hal itu tentu akan menjadi suatu indikasi tersendiri kenetralan atau keindependensian seorang kepala desa yang menjadi kelemahan di dalam suatu proses penyelesaian persengketaan yang terjadi di desa setempat tidak menutup kemungkinan, kedekatan yang terjalin itu kepala desa memberikan putusan yang memihak dari salah satu pihak yang bersengketa.

\section{KESIMPULAN}

Mayoritas masyarakat pedesaan menyelesaikan sengketa tanah kepada kepala desa dikarenakan minimnya pemahaman penyelesain konfilik dan mekanisme di pengadilan yang membutuhkan waktu panjang, sehingga biaya yang dikeluarkan juga sangat tinggi mengakibatkan masyarakat enggan untuk menyelesaikan permasalahan di pengadilan. Dampak yang timbulkan dari penyelesaian sengketa lewat kepala desa terdiri atas dampak positif dan dampak negatif. Adapun dampak positif yang ditimbulkan dari penyelesaian sengketa lewat kepala desa antara lain tidak mengeluarkan banyak biaya, dibandingkan penyelesaian sengketa melalui jalur pengadilan, dan juga dapat disesuaikan dengan kelonggaran waktu para pihak untuk menyelesaikan persengketaan, 
serta dapat mempermudah proses penganalisisan pokok-pokok latar belakang terjadinya persengketaan. Selain itu juga dampak negatif penyelesaian sengketa lewat kepala desa antara lain kompetensi kepala desa yang sangat minim, dan juga hasil keputusan kepala desa yang tidak memberikan kepastian hukum, selain dari pada itu tidak menutup kemungkinan kepala desa yang tidak bersikap netral. Oleh karena untuk memaksimalkan peran kepala desa diperlukan edukasi yang dilakukan oleh stakeholder agar terciptanya kesepakatan dalam sebuah mediasi.

\section{DAFTAR PUSTAKA}

Abbas, Syahrizal, Mediasi Dalam Hukum Syariah, Adat, dan Hukum Nasional (Jakarta: Kencana Prenada Media, 2009).

Achmad, Ali Chomzah, Penyelesaian Sengketa Hak Atas Tanah (Jakarta: Prestasi Pustaka Publisher, 2003).

Campbell, Henry Black, Black's Law Dictionary (USA: Min West Publishing Co, 1990).

Goldberg, Stephen, Dispute Resolution Negotiation, Mediation and Other Processes (New York: Little Brown and Company, 1992).

Juniasri, Mirda, Proses Permohonan Hak Atas Tanah Bekas Tanah

Partikelir di Kelurahan Cipinang Kecamatan Pulo Gadung Jakarta Timur Universitas Diponegoro, 2004) [unpublished].

Moore, Christopher W, The Mediation Process: Practical Strategies for Resolving Conflict (San Fransisco: Jossey-Bass Publisher, 2003).

Sinaga, Henry, Disharmonisasi Undang-Undang Pokok Agraria dengan Undang-Undang Sektoral Pengelolaan Sumber Daya Alam di Indonesia Universitas Sumatera Utara, 2017) [unpublished]. 
Wignjosoebroto, Soetandyo, Dari Hukum Kolonial Ke Hukum Nasional: suatu kajian tentang dinamika sosial-politik dalam perkembangan hukum (Yogyakarta: PT Raja Grafindo Persada, 1994).

Abrianto, Bagus Oktafian, "Eksistensi Peraturan Desa Dalam Sistem Ketatanegaraan Dan Perundang-Undangan Di Indonesia" (2011) 26:3 Yuridika 219-246.

Ahmad, Kamaluddin \& Ongki, "Peran Kepala Desa Dalam Menyelesaikan Konflik Antar Masyarakat Berdasarkan Peraturan Pemerintah Nomor 2 Tahun 2015 (Studi Kasus Di Desa Renda Kecamatan Belo Kabupaten Bima)" (2019) 7:1 Civ Pendidikan-Penelitian-Pengabdian Pendidik Pancasila dan Kewarganegaraan 58-69.

Alkostar, Artidjo, "Masalah Mafia Peradilan dan Penanggulangannya" (2002) 9:21 J Huk IUS QUIA IUSTUM 18.

Anatami, D, "Tanggung Jawab Siapa, Bila Terjadi Sertifikat Ganda Atas Sebidang Tanah" (2017) 12:1 J Huk Samudra Keadilan 117.

Astuti, Ana Puji \& Anike NUrmalita Rps, “Teknologi Komunikasi Dan Perilaku Remaja" (2018) 3:1 J Anal Sosiol 91-111.

Badruzaman, Dudi, "Perlindungan Hukum Tertanggung dalam Pembiayaan Klaim Asuransi Jiwa" (2019) 3:1 Amwaluna J Ekon dan Keuang Syariah 96-114.

Budiyanto, Budiyanto, "Penerapan Keadilan Restoratif (Restorative Justice) Dalam Penyelesaian Delik Adat" (2018) 1:1 Papua Law J 81-100.

Faisal, "Mediasi Penal dalam Penyelesaian Sengketa di Luar Pengadilan" (2011) 6:1 Pranata Huk 81-90. 
Hariyono, Teguh, "Mediasi Penal sebagai Alternatif Upaya Penyelesaian Perkara Pidana di Luar Pengadilan" (2021) 2:1 J Penegakan Huk dan Keadilan 1-18.

Huda, Anam Miftakhul \& Vembita Sapna Key, "Model Guyup Rembug Dalam Penyelesaian Konflik: Pada Konflik Antara Forpak Dengan Karang Taruna Di Desa Sidodadi" (2018) 4:2 Translitera J Kaji Komun dan Stud Media 1-16.

Kapindha, Ros Angesti Anas, Salvatia Dwi M \& Winda Rizky Febrina, "Efektivitas dan Efisiensi Alternatif Dispute Resolution (AD) Sebagai Salah Satu Penyelesaian Sengketa Bisnis di Indonesia" (2014) 4 Priv Law 1-14.

Mahfiana, Layyin, "Sengketa Kepemilikan Hak Atas Tanah di Kabupaten Ponorogo" (2013) 7:1 Kodifikasia 83-102.

Mali, Fransiskus X Gian Tue, “Negara vs Masyarakat: Konflik Tanah di Kabupaten Nagekeo, NTT" (2015) 11:2 J Kaji Polit Dan Masal Pembang 1657-1666.

Marsella, "Perspektif Penanganan Sengketa Pertanahan Di Badan Pertanahan Nasional" (2015) 2:2 J Ilm Penegakan Huk 101-107. Mulyadi, "Konflik Sosial Ditinjau Dari Segi Struktur dan Fungsi" (2002) 14:3 Humaniora 1-18.

Nainggolan, Samuel Dharma Putra, "Kedudukan Kepala Desa Sebagai Hakim Perdamaian" (2018) 3:1 Ubelac 54-67.

Ningrum, Herlina Ratna Sambawa, "Analisis Hukum Sistem Penyelesaian Sengketa Atas Tanah Berbasis Keadilan" (2014) 1:2 J Pembaharuan Huk 219-227.

Nurdin, Maharani, "Akar Konflik Pertanahan di Indonesia" (2018) 3:2 J Huk Positum 126-141. 
Panjaitan, Budi Sastra, "Pengadilan Landreform Sebagai Wadah Penyelesaian Kasus Pertanahan" (2020) 4:1 Justitia J Huk 19-38.

Prasetya, Dimas Ramdhana, "Analisis Pegelolaan Pengaduan Masyarakat dalam Rangka Pelayanan Publik ( Studi Pada Dinas Komunikasi dan Informatika Kota Malang )" (2013) 1:6 J Adm Publik 1151-1158.

Rahayu, Sri Lestari, Mulyanto \& Anti Mayastuti, "Penguatan Fungsi Kepala Desa Sebagai Mediator Perselisihan Masyarakat Di Desa" (2016) 95:2 Yust J Huk 340-360.

Rosidin, Utang, "Partisipasi Masyarakat Desa Dalam Proses Pembentukan Peraturan Desa yang Aspiratif" (2019) 4:1 J Bina Mulia Huk 168-184.

Rusli, Zaili, Chalid Sahuri \& Dadang Mashur, "Penerapan Social Enterpreneurship dalam Memberdayakan Masyarakat Miskin Perkotaan" (2011) 2:2 J Kebijak Publik 70-83.

Syafrida, "Alternatif Penyelesaian Sengketa sebagai Solusi Mewujudkan Asas Pemeriksaan Perkara 'Sederhana, Waktu Singkat dan Biaya Murah'" (2020) 7:4 SALAM J Sos dan Budaya Syar-i 353-370.

Warman, Kurnia \& Syofiarti, "Pola Penyelesaian Sengketa Tanah Ulayat di Sumatera Barat (Sengketa antara Masyarakat vs Pemerintah)" (2012) 41:3 Masal Huk 407-415.

Sekretariat Nasional Konsorsium Pembaruan Agraria (KPA), Catahu 2020 KPA Edisi I: Laporan Konflik Agraria di Masa Pandemi dan Krisis Ekonomi, by Sekretariat Nasional Konsorsium Pembaruan Agraria (KPA) (Jakarta, 2021). 
Spence, Joseph, "Types of Mediators to Select From", (2010), online: Ezne Artic <https://ezinearticles.com/?Types-of-Mediators-toSelect-From\&id=5133589> 